\title{
Perlindungan Hukum Terhadap Pekerja Anak, Kajian Ketentuan United Nations Convention On The Right Of The Child
}

\author{
Lucia Charlotta Octovina Tahamata \\ Program Doktor Ilmu Hukum Pascasarjana Universitas Hasanuddin, Makassar, Indonesia \\ E-mail: luciatahamata@gmail.com
}

\begin{abstract}
The State has the duty and role in protecting and guaranteeing the human rights of its citizens. Violations of human rights often occur against vulnerable groups, one of which is children. Children as vulnerable groups have special rights due to their limitations, so they need protection. Countries in the world agree to review the protection of children by signing and ratifying Convention on the Right of the Child 1989. This Convention specifically regulates the protection and guarantee of the rights of the child to be undertaken by States Parties. However, violations of child rights continue to occur, one of them being child labor. Working causes children to lose their right to grow, grow, play and receive education. Writing method used is normative juridical research, that is by analyzing the legal issues contained in legislation related to the problem under study. The problem approach used by the conceptual approach and the legislative approach, using the source of primary legal material as a reference to complete the writing and collection of legal materials is done by using literature study techniques which are then analyzed through qualitative techniques. The results show that the state should be responsible for child labor under the Convention on the Right of the Child 1989, but the binding force of the rule has not been implemented by the state in accordance with the existing material and conditions. The evidence can be seen from various cases of child rights violations that still occur, such as children who are still employed.
\end{abstract}

Keywords : State Responsibility, Child Labor.

\section{A. PENDAHULUAN.}

Anak adalah setiap manusia yang berusia dibawah delapan tahun kecuali, berdasarkan Undang-Undang yang berlaku untuk anak-anak, kedewasaan telah dicapai lebih cepat $^{1}$. Selanjutnya dalam Konvensi Hak Anak 1959 dinyatakan bahwa karena ketidakmatangan jasmani dan mentalnya,

1 Pasal 1 Covention On The Right Of The Child 1989 
anak memerlukan pengamanan dan pemeliharaan khusus termasuk perlindungan hukum yang layak sebelum dan sesudah kelahiran. ${ }^{2}$ Undang-Undang Nomor 39 tahun 1999 tentang Hak Asasi Manusia (HAM) mendefinisikan anak sebagai setiap manusia yang berusia dibawah 18 tahun dan belum menikah, termasuk anak yang masih dalam kandungan. Sementara Undang-Undang Nomor 23 tahun 2002 tentang Perlindungan Anak juga mendefinisikan anak sebagai sesorang yang belum berusia 18 tahun, termasuk anak yang masih dalam kandungan.

Anak sebagai kelompok rentan memiliki hak-hak khusus akibat keterbatasannya. Hal ini membuat anak memerlukan perlindungan akan hak-haknya. Perlindungan anak adalah segala kegiatan untuk menjamin dan melindungi anak dan hak-haknya agar dapat hidup, tumbuh, berkembang, dan berpartisipasi secara optimal sesuai dengan harkat, tumbuh, berkembang, dan berpartisipasi secara optimal sesuai dengan harkat dan martabat serta kemanusian, sehingga mendapat perlindungan dari kekerasan dan diskriminasi $^{3}$

Pada tahun 1989, negara-negara didunia lewat PBB (Perserikatan Bangsa-Bangsa), menandatangani United Nations Convention on the Rights of the child atau Konvensi Hak-hak Anak Perserikatan Bangsa-Bangsa. Konvensi ini adalah adalah sebuah Konvensi Internasional yang mengatur hak-hak sipil, politik,ekonomi, sosial dan kultural anak-anak. Negara -negara yang meratifikasi konvensi internasional ini terikat untuk menjalankannya sesuai dengan hukum internasional. Hal ini sesuai dengan salah satu asas hukum internasional yaitu asas Pacta Sund

2 Chandra Gautama, Konvensi Hak aanak; Panduan bagi jurnalistik, Lembaga studi Pers Pembangunan , Jakarta, h, 21

3 Pasal 1 ayat (2) UU No 23 Tahun 2002, tentang Perlindungan Anak
Servanda. Menurut asas ini, perjanjian mengikat seperti Undang_Undang bagi para pihak yang melakukan perjanjian. ${ }^{4}$

Meski secara internasional banyak konvensi mengatur tentang perlindungan akan hak-hak anak dan diratifikasi oleh banyak negara, pelangaran hak asasi manusia pada anak-anak tetap marak terjadi didunia. Salah satu masalah yang harus memperoleh perhatian khusus adalah isu pekerja anak. Pekerja anak yang harus memperoleh perhatian khusus adalah isu pekerja anak. Pekerja anak adalah sebuah istilah untuk memperkerjakan anak dibawa umum. Istilah pekerja anak adalah sebuah istilah untuk memperkerjakan anak dibawah umur. Istilah pekerja anak memiliki konotasi pengeksploitasi anak-anak dibawah umur atas tenaga mereka. Isu ini telah menggobal karena begitu banyak anak-anak diseluruh dunia yang bekerja pada usia sekolah. Pada kenyataannya isu pekerja anak bukan sekedar isu anak menjalankan pekerjaan dengan memperoleh upah, akan tetapi lekat sekali dengan eksploitasi, pekerjaan berbahaya, terlambatnya akses pendidikan dan menghambat perkembangan fisik, psikis dan sosial anak. Bahkan dalam kasus tertentu, pekerja anak telah masuk sebagai kualifikasi anak-anak yang bekerja pada situasi yang paling tidak bisa ditolerir. ${ }^{5}$

Dalam Convention on the Right of the child 1989, yang telah diratifikasi oleh pemerintah Indonesia dengan keputusan Presiden Nomor 36 tahun 1990, memuat empat prinsip umum tentang hak anak, yaitu;

1) Bahwa anak-anak dibekali dengan hak-hak tanpa kecuali

2) Bahwa anak-anak mempunyai hak

4 Sefriani, Hukum Internasional suatu Pengantar, edisi kedua, Raja Grafindo Persada, Jakarta, 2016, h, 35

5 Muhammad Joni dan Zulechaina Z. Tanamas, Aspek Hukum Perlindungan Anak dan Perspektif Konvensi Hak-hak Anak. Citra Aditya Bakti, Bandung, 1999, h, 45 
untuk hidup

dan

berkembang

3) Bahwa kepentingan anak harus menjadi pertimbangan utama dalam semua keputusan atau tindakan yang mempengaruhi anak

4) Bahwa anak-anak diperbolehkan untuk berpartisipasi sebagai peserta aktif dalam segala hal yang mempengaruhi hidup ${ }^{6}$

Salah satu bentuk pekerja anak yang terdapat di Indonesia adalah menjadi buruh pada sektor pertanian. Organisasi Buruh Internasional (ILO) memperkirakan lebih dari 1,5 juta anak usia 10-17 tahun bekerja dipertanian Indonesia setiap tahun . Departemen tenaga kerja Amaerika Serikat (DOL) melaporkan lebih dari $60 \%$ buruh anak usia 10-14 tahun di Indonesia terlibat dalm sektor pertanian, termasuk perikanan, serta dalam produksi karet, kelapa sawit, dan tembakau. Menurut Kementerian Ketenagakerjaan dan Transmigrasi, sekitar 400.000 anak diseluruh Indonesia terlibat menjadi pekerja anak disektor perikanan maupun pertanian. Menurut ILO, jawa Timur dan jawa Tengah adalah provinsi dengan pekerja anak terbesar di sektor pertanian, ${ }^{7}$

Tugas dari anak-anak yang bekerja sebagai buruh di ladang tembakau adalah mempersiapakan ladang, menanam bibit temakau, menyiram, memberikan pupuk dan pestisida, memanen daun tembakau, memotong, mengeringkan sampai menyortir daun tembakau yang telah kering. ${ }^{8}$

Anak-anak yang bekerja di ladang tembakau terkena resiko karacunan akut akibat terpapar nikotin, pestisida beracun,

6 Depdiknas, Pedoman teknis Pelayanan Pendidikan Bagi pekerja anak sektor informal, Depdiknas, Jakarta, 2001, h, 17

7 Human Rights Watch, The Harvest is in My Blood, Hazardous Child Labour in Tobacco Farming in Indonesia, USA, 2016, h, 13

${ }^{8}$ Human Right, watch, Op, Cit, h, 33 cedera akibat suhu panas, mengalami masalah pernapasan, dan iritasi mata dan kulit. Sebagian besar anak-anak menderita sakit dan kelelahan karena terus terlibat dalam pekerjaan berulang dan mengakut beban yang cukup berat. Mereka juga tidak dilengkapi alat pelindung saat bekerja diketingian. Selain itu, anak-anak yang bekerja mengunakan benda tajam, tanpa sengaja sering melukai diri sendiri. ${ }^{9}$ Hal ini bertentangan dengan aturan dalam Konvensi Hak Anak tahun 1989, yang telah diratifikasi oleh Indonesia.

Menurut pasal 32 ayat (1) Konvensi Hak Anak tahun 1989 menyebutkan bahwa; Negara-Negara peserta mengakui hak anak untuk dilindungi dari eksploitasi ekonomi dari melakukan setiap pekerjaan yang mungkin akan berbahaya atau menganggu pendidikan anak, atau membahayakan kesehatan atau perkembangan fisik, mental, spritual, moral atau sosial anak. Dalam pasal 3 ayat ( 2) konvensi ini juga disebutkan bahwa negara-negara peserta berusaha untuk menjamin bahwa anak akan mendapat perlindungan dan perawatan seperti yang diperlukan bagi kesejahteraannya, dengan memperhatikan hak-hak dan tangungjawab orang tua, wali atau perorangan lainnya yang secara hukum bertangungjawab atas anak itu, dan untuk tujuan ini akan mengambi semua langkah legislatif dan administratif yang tepat.

Indonesia merupakan salah satu negara yang telah ikut berpartisipasi dengan menandatangani dan meratifikasi beberapa konvensi terkait dengan perlindungan hak asasi manusia, yang lebih khusus adalah hak anak. Namun karena rendahnya penerapan serta penegakan hukum di Indonesia, menyebabkan banyak pelangaran hak asasi terhadap anak yang terus terjadi. Maka perlu adanya peran negara dalam memberikan perlindungan dan perawatan

9 Human Right Watch, Op Cit , h. 39 
anak bagi kesejahteraan dan masa depan anak .

Dari uraian latar belakang tersebut, maka yang menjadi permasalahan dalam tulisan ini adalah bagimanakah perlindungan hukum terhadap pekerja anak, kajian ketentuan Unted Nations Conventions On Thr Right Of The Child 1989

\section{B. PEMBAHASAN}

\section{Kewajiban Asasi Negara Dalam Perlindungan Hak-Hak Asasi}

Salah satu syarat negara hukum adalah adanya perlindungan dan jaminan akan hak asasi manusia. Kewajiban negara adalah untuk menjamin hak asasi manusia menjamin sistem hukum yang adil, mensejahteraan rakyat serta memberikan jaminan dan perlindungan sosial. Dalam Vienna Declaration and Programme of action 1993, kewajiban negara merupakan kewajiban hukum yang diamanatkan dalam sebuah perjanjian (treaty obligation). Hak asasi manusia dan kebebasan fundamental adalah hak lahirnya semua manusia dan perlindungannya adalah tangungjawab pertama pemerintah. ${ }^{10}$ Deklarasi ini juga menegaskan agar negara-negara mengambil komitmen serius untuk memenuhi kewajiban mereka dalam memproklamasikan penghormatan unversal, mematuhi dan melindungi semua hak asasi manusia serta kebebasan fundamental yang sesuai dengan PBB instrumen lain yang berkaitan dengan HAM ,serta hukum internasional, seperti yan disebutkan dalam Pasal 1 deklarasi ini berbunyi;

" the world conference on human right reaffirms the solemn commitmen of all statea to fulfil their obligations to promote universal respect for, and onservance and protection of, all human right and fundamental

10 Pasal 1 Vienna Declaration and Programme of action 1993 freedoms for all in accordance with cahrter of the unted nations, other instrumen relating to human right, and international law. The unversal nature of these right and freedoms is beyond question. Human right and fundamental fredoms are the birthright of all human being their protection and promotion is the first responsibility of Governments.

Menurut the Limburg Priciples on the implementation of internasional covenant on ekonomi and sosial and cultural Rights 1986, hak manusia merupakan kebebasan mendasar yang didalamnya terdapat hak-hak ekonomi ,sosial dan budaya, yang merupakan bagian integral hukum hak asasi manusia internasional, dan negara memiliki kewajiban untuk melindungi hak-hak tersebut.

Negara memiliki kewajiban untuk melindungi hak setiap warga negaranya tanpa terkecuali, yang didalamnya juga terdapat hak-hak kelompok rentan, yang salah satunya adalah anak-anak. Anak adalah generasi muda bangsa yang dilindungi, karena masa depannya merupakan masa depan sebuah negara. Hak-hak anak merupakan hak kostitusional (constitutional right), yang menurut Prof Jimly Asshiddiqie adalah hak-hak yang dijamin didalam dan oleh Undang Undang Dasar Negara Republik Indonesia $1945 .^{11}$

Prinsip Limburg menyatakan bahwa semua negara memiliki kewajiban untuk segera mengambil langkah-langkah demi terwujudnya hak-hak yang tercermin di dalam perjanjian secara utuh. Indonesia membuktikan keseriusan dalam melakukan perlindungan dan jaminan terhadap hak anak. Hal ini terbukti saat Indonesia turut serta dalam menandatangani dan meratifikasi convention on the Right of the child 1989

11 Jimly Asshiddiqie, kontitusi \& konstitusionalisme Indonesia, Edisi Revisi, Konstitusi Press, Jakarta, 2005, h, 152 
(Konvensi Hak anak 1989). Indonesia meratifikasi Konvensi Hak anak 1989 melalui keputusan Presiden no 36 tahun 1990. Dengan meratifikasi Konvensi Hak Anak 1989, Indonesia telah memikul sebuah kewajiban untuk menghormati dan melindungi hak-hak anak. Indonesia juga mengeluarkan sejumlah aturan yang menjadi landasan dalam praktek perlindungan serta menjamin hak anak, sebagai sebuah langkah sesuai dengan yang disebut dalam prinsip Limburg.

Dalam UU Nomor 23 tahun 2002 tentang Perlindungan Anak menurut pasal 59 menyatakan bahwa, pemerintah dan lembaga negara berkewajiban dan bertangungjawab untuk memberikan perlindungan khusus kepada anak dalam situasi darurat, anak yang berhadapan dengan hukum, anak-anak dari kelompok minoritas dan terisolasi, anak yang tereksplotasi secara ekonomi dan atau seksual serta yang diperdagangkan.

Secara internasional, perlindungan terhadap anak diatur dalam Konvensi Hak Anak 1989, yang mewajibkan negara peserta untuk memberikan perlindungan dan perawatan khusus pada anak karena ketidakmatangan fisik dan mentalnya. Dalam Pasal 3 ayat (2) Konvensi hak Anak 1989 disebutkan bahwa negara-negara peserta harus berusaha menjamin bahwa anak akan mendapatkan perlindungan dan perawatan seperti yang diperlukan bagi kesejateraannya, dengan memperhatikan hak-hak dan tangungjawab atas anak dan untuk tujuan ini, akan mengambil semua langkah bahwa setiap anak memiliki hak yang melekat pada kehidupan dan negara akan menjamin hal ini sampai batas maksimal kelangsungan hidup dan pengembangan anak. $^{12}$

Menurut Chandra Gautama, ada 31 hak anak yang termuat dalam Konvensi Hak anak 1989 13 yaitu hak untuk kelangsungan hidup dan berkembang hak untuk mendapatkan nama, hak untuk

\footnotetext{
12 Pasal 6 Konvensi, op cit, hal 69-70
}

mendapatkan kewarganegaraan, hak untuk mendapatkan indentitas, hak untuk mendapatkan standar hidup yang layak, hak untuk mendapatkan standat kesehatan yang paling tinggi, hak untuk mendapatkan perlindungan khusus jika mengalami eksploitasi dalam penyalagunaan obat-obat, hak untuk mendapatkan perlindungan khusus jika mengalami eksploitasi seksual dan penyalagunaan seksual, hak untuk mendapatkan perlindungan hukum dari penculikan penjualan dan perdagangan anak-anak, hak untuk mendapatkan perlindungan khusus jika mengalami eksploitasi sebagai kelompok minoritas atau masyarakat adat, hak untuk hidup dengan orang tua, hak untuk tetap berhubungan dengan orang tua bila dipisahkan dari salah satu orang tua, hak untuk mendapatkan pelatihan keterampialn, hak untuk berkreasi, hak untuk bermain, hak untuk berpartisipasi dalam kegiatan seni dan kebudayaan, hak untuk mendapatkan perlindungan khusus dalam situasi yang genting, hak untuk mendapatkan perlindungan khusus sebagai pengungsi, hak mendapatkan perlindungan pribadi, hak untuk mendapatkan perlindungan dari siksaan, hak untuk mendapatkan perlindungan dari siksaan, hak untuk mendapatkan perlindungan dari penangkapan yang sewenang-wenang, hak untuk mendapat perlindungan dari perampasan kebebebasan dan hak untuk mendapatkan pendidikan dasar secara Cuma-Cuma.

Pasal 19 ayat (a) Konvensi Hak anak 1989 menyebutkan negara-negara peserta akan mengambil semua langkah legislatif,administrasi,sosial dan pendidikan untuk melindungi anak dari semua bentuk kekerasan fisik dan mental, cidera atau penyalagunaan, penelantaraan atau pengakuan salah atau eksploitasi , termasuk penyalagunaan seksual, sementara berada dalam asuhan orang tua, wali atau orang lain yang memelihara anak 


\section{Perlindungan Hak Anak di Indonesia Menurut Convention On The Rights Of the Child 1989}

Konvensi hak anak terdiri atas 54 (lima puluh empat) pasal yang berdasarkan materi hukum mengatur mengenai hak-hak anak dan mekanisme implementasi hak anak oleh negara peserta yang meratifikasi Konvensi Hak anak. ${ }^{14}$ Indonesia telah meratifikasi konvensi Hak Anak 1989 melalui Keputusan Presiden No 36 Tahun 1990. Selanjutnya pada tahun 2002 pemerintah Indonesia mengeluarkan UU No 23 tahun 2002 Tentang Perlindungan Anak . Perlindungan anak sebagai sebagai upaya lanjutan dalam melindungi hak-hak anak. Perlindungan akan hak-hak anak juga dijamin dalam UUDNRI tahun 1945, pada pasal 28B ayat (2) yang berbunyi setiap anak berhak atas kelangsungan hidup, tumbuh dan berkembang serta berhak atas perlindungan dari kekerasan dan diskriminasi.

Dalam Pasal 24 Konvensi Hak Anak 1989 ,terdapat beberapa langkah bagi negara-negara peserta yang harus dilakukan dalam mengimplementasi hak mendasar bagi hidup anak yaitu ;untuk melaksanakan menurunkan angka kematian bayi dan anak, menyediakan pelayanan kesehatan yang diperlukan khususnya pelayanan kesehatan, memberantas penyakit dan kekurangan gizi termasuk dalam rangka pelayanan kesehatan sebelum dan sesudah melahirkan bagi ibu-ibu, memperoleh serta akses pada pendidikan dan mendapat dukungan pada pengetahuan dasar tentang kesehatan dan gizi, mengembangkan perawatan kesehatan pencegahan, bimbingan bagi orang tua serta penyuluhan keluarga berencana, dan mengambil tindakan untuk menghilangkan praktik tradisional yang berprasangka buruk terhadap pelayanan kesehatan dan pengembangan kerja sama internasional.

14 Muhamad Joni dan Zulchaina Z. Tanamas
Menurut penelitian Human Right Watch dalam mewawancarai anak-anak yang bekerja dipertanian tembakau, tugas mereka adalah; mengali tanah dengan cangkul untuk mempersiapkan ladang, menanam bibit tembakau, menyiram tanaman, memberi pupuk, mencabuti bunga dan menyuburkan daun dari tanaman, menyingkirkan cacing dan serangga dengan tangan, mencampur dan memberi pestisida memanen daun tembakau dengan tangan, membawa bundelan daun daun tembakau yang telah dipanen,mengatur tungku pemanas dilumbung pengering, mengambil gelantang tembakau dari gudang pengering, melepaskan sujuen daun tembakau yang sudah kering dari gelantang, menyortir dan mengelompokan tembakau kering dan mengikat tembakau kering dalam bal. ${ }^{15}$. Anak yang diwawancarai Human Rights Watch untuk laporan ini mengatakan mereka melakukan lebih dari satu tugas.

Dalam peraturan nasional, pasal 13 UU NO 23 tahun 2003 tentang Perlindungan Anak menyebutkan bahwa setiap anak selama dalam pengasuhan orang tua, wali atau pihak lain manapun yang bertanggungjawab atas pengasuhan , berhak mendapatkan perlindungan dari perlakukan diskriminasi,eksploitasi baik ekonomi maupun seksual, penelantaran, kekejaman,, kekerasan, dan penaaniayaan ketidakadilan dan perlakuan salah lainnya. Negara dalam hal ini memiliki tangungjawab, seperti yang disebutkan dalam pasal 20 UU No 35 tahun 2014 tentang perubahan atas UU NO 23 tahun 2002 tentang Perlindungan Anak disebutkan bahwa negara,pemerintah,pemerintah daerah, masyarakat, keluarga dan orang tua atau wali berkewajiban dan bertanggungjawab terhadap penyelengaraan perlindungan anak.

Lembaga negara independen yang secara khusus melakukan pemantauan

\footnotetext{
15. Human Rights Watch, Op Cit, h, 33.
} 
terhadap masalah perlindungan anak di Indonesia adalah Komisi Perlindungan Anak Indonsia (KPAI) ,yang dibentuk berdasarkan Pasal 74 UU Nomor 23 tahun 2002. Peran KPAI juga penting dalam memberikan perlindungan bagi hak anak. Hal ini dibuktikan dengan hasil pemantauan,evaluasi dan pengawasan terhadap pelangaran hak-hak anak di Indonesia,yang termasuk dalam hal ini pekerja anak.

Pada tangungjawab dalam memberikan perlindungan juga ada pemberian sanksi-sanksi bagi orang yang melibatkan atau memperkerjakan anak., yaitu Pasal 32 Konvensi Hak Anak 1989.

\section{PE N U T P}

Berdasarkan hasil penelitian dan pembahasan diatas maka dapat disimpulkan bahwa: Negara bertanggung jawab terhadap pekerja anak berdasarkan Convention on the Right of Child 1989, yang merupakan sebuah konvensi yang mengatur tentang perlindungan hak anak. Secara de jure, ketentuan-ketentuan hukum internasional yang telah diratifikasi dalam berbagai ketentuan hukum nasional Indonesia memiliki legally binding bagi negara dalam perlindungan terhapat hak-hak anak. Secara de facto, kekuatan mengikat dari ketentuan-ketentuan hukum tersebut belum diimplementasikan oleh negara sesuai dengan materi dan ketentuan-ketentuan hukum tersebut. Pembuktiannya dapat dilihat dari berbagai kasus pelanggaran hak-hak anak yang masih terjadi, seperti anak-anak yang masih tetap dipekerjakan, walaupun hal ini sangat ditentang oleh konvensi. Hal ini menunjukan derajat tanggung jawab negara masih sangat rendah dalam memberikan perlindungan bagi anak-anak yang belum semestinya dipekerjakan

\section{DAFTAR PUSTAKA}

Antonia Cassesse, Hak Asasi manusia di dunia yang berubah, yayasan obor Indonesia, Jakarta, 1994

Chandra Gautama, Konvensi Hak anak, panduan bagi jurnalistik lembaga studi pers pembangunan, Jakarta

Huala Adolf, Aspek-aspek negara dalam hukum internasional, edisi revisi, raja Grafindo Persada, Jakarta, 2002

Muhammad Joni dan Zullechaina Z Tanamas, Aspek Hukum Perlindungan Anak dan perspektif Konvensi hak-hak anak, citra Aditya Bakti, Bandung 1999

Sefriani, Hukum internasional suatu pengantar, edisi kedua, Raja Grafindo Persada Jakarta, 2016.

Jurnal Human Rights Watch the Harvest is in my Bload, Hazardous child Labour in Tobacco Farming in Indonesia, USA,20016. 